Rev. Int. Contam. Ambie. 37, 259-272, 2021

https://doi.org/10.20937/RICA.53696

\title{
FIRST EVIDENCE OF POTENTIAL TOXIC CYANOBACTERIA IN THE WATER-SEDIMENT INTERFACE OF A TROPICAL DRINKING WATER RESERVOIR
}

Primera evidencia de cianobacterias con potencial tóxico en la interfase agua-sedimento de un embalse de agua potable

\author{
Marisol SEPÚLVEDA-SÁNCHEZ ${ }^{1 *}$, Lina María ARISMENDI GONZÁLEZ ${ }^{1}$, \\ Clara María ARBOLEDA-BAENA ${ }^{1}$. Carlos Enrique MUSKUS LÓPEZ ${ }^{2}$. Elisabeth POHLON ${ }^{3}$, \\ Maria Teresa FLOREZ MOLINA ${ }^{1}$ and Jaime Alberto PALACIO BAENA ${ }^{1}$
}

${ }^{1}$ Grupo de Investigación en Gestión y Modelación Ambiental GAIA, Facultad de Ingeniería, Universidad de Antioquia, A.P. A1226, Calle 70 No. 52-21, Medellín, Colombia.

${ }^{2}$ Programa de Estudio y Control de Enfermedades Tropicales, Facultad de Medicina, Universidad de Antioquia, Medellín, Colombia.

${ }^{3}$ Department of Animal Ecology and Systematics, Justus-Liebig University, Heinrich Buff Ring 26, 35392 Gießen.

*Author for correspondence: marisol.sepulveda@udea.edu.co

(Received August 2019; accepted June 2020)

Key words: Riogrande II reservoir, Nostocales and Chroococcales cyanobacteria, mcy gen.

\begin{abstract}
The Nostocales and Chroococcales cyanobacteria can produce potent cyanotoxins and survive in deep zones of aquatic ecosystems by the formation of morphologically distinguishable resistance structures and temporarily latent colonies in sediments. The purpose of this study was to determine the presence and density of Nostocales and Chroococcales with toxic potential in the water-sediment interface. During four samplings in three locations of the drinking water reservoir Riogrande II, some physical and chemical variables and chlorophyll $a$ concentration of different spectral groups were measured, density of cyanobacteria was established by conventional microscopy, and mcyD and mcyE genes were detected by PCR. The environmental factors correlated with the abundance of cyanobacteria in the water-sediment interface were $\mathrm{pH}$, total phosphorus, and iron. The highest chlorophyll concentration was provided by Chlorophyceae, while chlorophyll from the cyanobacteria spectral group fluctuated between 0.07 and $3.6 \mathrm{mg} / \mathrm{L}$ in field samples. About $86 \%$ of the total cells number corresponded to the Microcystis complex while the Nostocales represented just 3.35 $\%$. It was possible to find evidence for cyanobacteria with toxic potential in the three sampling points through the detection of the mcyD and mcyE genes. The presence of these cyanobacteria is possibly related to their life cycle and the resuspension processes caused by the way river water enters the reservoir. Additionally, this is the first evidence that demonstrates the importance of the water-sediment interface as a reservoir of cyanobacteria with toxic potential, since they can recolonize the water column in ecosystems that supply drinking water.
\end{abstract}

Palabras clave: embalse Riogrande II, cianobacterias Nostocales y Chroococcales, gen mcy. 


\section{RESUMEN}

Las cianobacterias Nostocales y Chroococcales pueden producir diferentes cianotoxinas y sobrevivir en zonas profundas de los ecosistemas acuáticos mediante la formación de estructuras de resistencia morfológicamente distinguibles y de colonias temporalmente latentes en los sedimentos. El propósito de este estudio fue determinar la densidad y presencia de cianobacterias Chroococcales y Nostocales con potencial tóxico en la interfase agua-sedimento. Durante cuatro muestreos en tres locaciones del embalse de agua potable Riogrande II, se evaluaron algunas variables físicas y químicas, se midió la concentración de clorofila a de diferentes grupos espectrales, se estableció la densidad de cianobacterias por microscopía convencional y los genes mcyD y mcyE fueron detectados por PCR. Las variables ambientales que se correlacionaron con la abundancia de cianobacterias en la interfase agua-sedimento fueron $\mathrm{pH}$, fósforo total y hierro. La alta concentración de clorofila fue aportada por clorofíceas, mientras que la clorofila del grupo espectral cianobacteria fluctuó de 0.07 a $3.6 \mathrm{mg} / \mathrm{L}$ en las muestras de campo. Cerca del $86 \%$ del total de células encontradas pertenecieron al complejo Microcystis, mientras que las Nostocales representaron sólo el $3.35 \%$. Fue posible evidenciar cianobacterias con potencial tóxico en los tres puntos de muestreo mediante la detección de los genes mcyD y mcyE. Es posible que la presencia de cianobacterias esté relacionada con su ciclo de vida y con procesos de resuspensión, debido a la forma en que el agua ingresa a los tributarios del embalse. Ésta es la primera evidencia sobre la importancia de la interfase agua-sedimento como reservorio de cianobacterias con potencial tóxico que pueden llegar a recolonizar la columna de agua en embalses destinados al suministro de agua potable.

\section{INTRODUCTION}

Reservoirs supplied by tributaries from urban areas with a high degree of anthropic intervention usually experience eutrophication due to the increased load of nitrogen and phophorous (Boopathi and $\mathrm{Ki}$ 2014, Bonilla et al. 2015, Chaffin et al. 2018) which lead to massive growth of algae, and often the predominance of cyanobacteria (Latour et al. 2004, Latour and Giraudet 2004, Teixeira 2009, Ye et al. 2011, Quiblier et al. 2013). Furthermore, climate change, high temperature and light intensities are key factors that promote cyanobacteria proliferation (Elliott 2012, Boopathi and Ki 2014, Aguilera et al. 2018, Mesquita et al. 2019). These oxygenic photoautotrophic microorganisms belong to the Bacteria nomain and are widely distributed, as solitary cells or form colonies (Ladakis et al. 2006, Metcalf and Codd 2009, Teixeira 2009), such us planktonic organisms, epiphytic or benthic biofilms in aquatic environments (Quiblier et al. 2013, Aguilera and Echenique 2017).

Cyanobacteria of the order Nostocales (Anabaena, Aphanizomenon, Dolichospermum, Cylindrospermopsis, Sphaerospermopsis) develop resistance structures called akinetes, which morphologically and physiologically correspond to differentiated cells originating from vegetative cells (Head et al. 1999, Karlsson-Elfgren and Brunberg 2004, Aguilera et al. 2017, Gangi et al. 2020), giving them the ability to survive under unfavorable conditions for long periods, like the sediment environment (Everson et al. 2011).

Cyanobacteria of the Chroococcales order, such as the genera Microcystis, dominate the taxocenosis of the phytoplankton in several eutrophic aquatic ecosystems (Brunberg and Blomqvist 2002, Misson and Latour 2012). Although they do not form resistance structures as Nostocales, they can survive as inactive colonies in surface sediments as part of their cycle life (Head et al. 1999, Ståhl-Delbanco et al. 2003, Latour et al. 2004, Cirés et al. 2013), keeping some cellular activity, the colonial and cellular structure and its microcystin content (Tsujimura et al. 2000, Misson and Latour 2012).

Studies from aquatic environments of the temperate zones show evidence for a benthic phase of the life cycle of some cyanobacteria taxa (Reynolds et al. 1981, Boström et al. 1989, Misson and Latour 2012) and the factors which promote their proliferation have been identified (Brunberg and Blomqvist 2002, Cao et al. 2016). The cyanobacteria studies of Lürling et al. (2013) and Mesquita et al. (2019), under laboratory 
conditions, show that increasing temperature was determining for the presence of cyanobacteria by affecting the mixing regime leading to stratification. However, in deepest tropical environments the role of the water-sediment interface and the dynamic of these micro-organisms is unknown so far, particularly the reinvasion of the water column.

Cyanobacteria with the ability of cyanotoxin segregation such as dermatoxins, hepatotoxins and neurotoxins constitute a health risk for humans and animals by attacking the skin, the digestive system and the nervous system (Boopathy and Ki 2014). In 1985 Bula-Meyer published the first report of human and domestic animal intoxication events because of water consumption containing cyanotoxins in Colombia. Subsequently, Mancera and Vidal (1994) reported massive mortality of fish because of a cyanobacteria bloom. Since 2007 reports from cyanotoxin contamination of the Riogrande II reservoir, the principal drinking water resource of one of the most densely populated departments of Colombia, exist. There, the presence of cyanobacterial strains of the order Nostocales (Dolichospermum cf. Planctonicum, Sphaerospermopsis cf. Torque-reginae) and Chroococcales (Microcystis cf. Wesenbergii, Microcystis cf. Aeruginosa) are found in the photic zone of the reservoir (Correa 2008, Herrera et al. 2015, Palacio et al. 2015).
The potential toxicity and effects of cyanotoxins from the cyanobacteria in this reservoir are still unknown. So far, the view of investigations in Colombia was exclusively on the photic zone of the reservoir as part of a cyanobacteria monitoring program using indirect biological indicators such as chlorophyll $a$, biovolume and physical and chemical parameters. Therefore, the aim of this research was to determine the toxic potential of cyanobacteria from the watersediment interface of Riogrande II, through the detection of the mcyD and mcyE genes. This toxicity genes detection technique was recently developed for the identification of toxic cyanobacteria strains by the amplification of the mcy genes (Bonilla et al. 2015). It is a highly specific method that allows the determination even in very low cell density (Sipari et al. 2010, Chorus 2012).

\section{MATERIALS AND METHODS}

\section{Study area}

The Riogrande II reservoir is located between $75^{\circ}$ $32^{\prime} 30^{\prime \prime}-75^{\circ} 26^{\prime} 10^{\prime \prime} \mathrm{W}$ and $6^{\circ} 33^{\prime} 50^{\prime \prime}-6^{\circ} 28^{\prime} 07^{\prime \prime} \mathrm{N}$, 2200 masl in the central Andes in northeastern Colombia at a distance of $55 \mathrm{~km}$ from Medellín City (Palacio et al. 2015) (Fig. 1). It has a capacity of $253000000 \mathrm{~m}^{3}$, a maximum depth of $47.2 \mathrm{~m}$ in

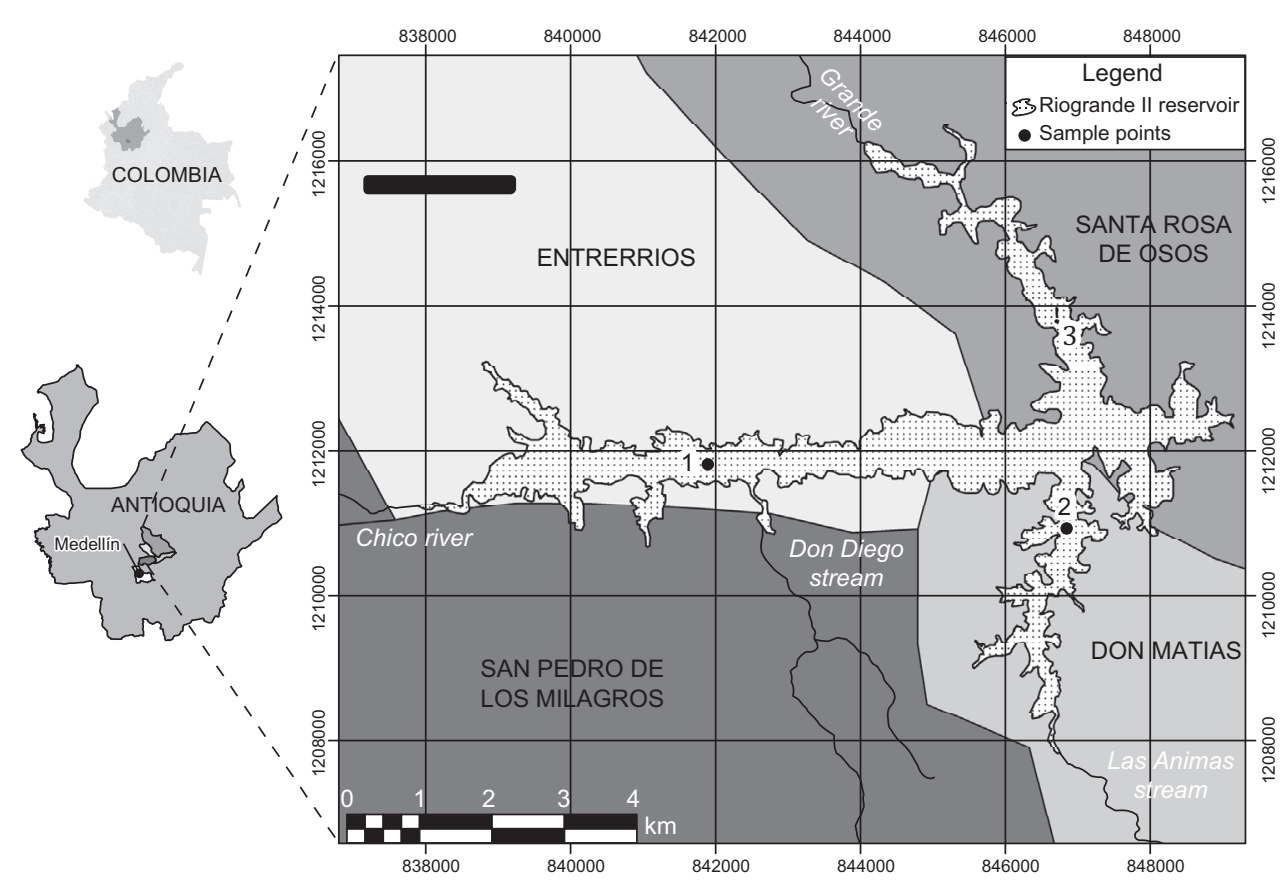

Fig. 1. Location of the Riogrande II reservoir and sampling sites 1 (Chico river entry), 2 (Las Ánimas entry) and 3 (Grande river entry). 
normal operating conditions and floods an area of approximately 1100 ha. It has a "T" shape, with its major axis oriented in the west-east direction and it is formed by the damming of the waters of the Grande and Chico rivers and Las Ánimas stream. The reservoir is employed to supply drinking water for 1.4 million inhabitants of the metropolitan area of Medellín (40\% of the total population) and is used for hydroelectric generation (Palacio et al. 2015). The soils are rich in volcanic minerals and contain a multitude of organic matter. In the rivers' basins, there are tomato and potato crops, dairy ranching and swine breeding, and the riverbeds are receptors of agrochemical residues and wastewater discharges from urban centers (Palacio-Baena 2015).

\section{Sampling}

Samples were taken during four campaigns: December 2014 (T1), and March (T2), April (T3) and May (T4) 2015, in three sampling sites: Chico river entry (1), Las Ánimas entry (2) and Grande river entry (3) as can be observed in figure 1. Temperature, concentration of total chlorophyll $a$ and chlorophyll of the different spectral groups in the water-sediment interface were measured using a Fluoro Probebbe-Moldaenke fluorometer (with MODC factor correction integrated for dissolved organic substances and a resolution of $0.01 \mu \mathrm{g}$ chl-a/L). This equipment allows in situ differentiation of four spectral groups of algae (Chlorophyta, Cyanobacteria, Bacillariophyta/Dinophyta and Cryptophyta), based on the different patterns of fluorescence emission after excitation at five wavelengths $(525,570,610,590$, and $470 \mathrm{~nm})$, determined by the composition of their antenna pigments (Beutler et al. 2002, Gregor and Maršálek 2004). $\mathrm{pH}$ and electrical conductivity were measured in situ as well as by means of a CTD SBE-25 profiler (Sea-BirdElectronics).

For the determination of total phosphorus (PT), orthophosphates $\left(\mathrm{PO}_{4}{ }^{3-}\right)$, organic nitrogen (NO), nitrites $\left(\mathrm{NO}_{2}{ }^{-}\right)$, nitrates $\left(\mathrm{NO}_{3}{ }^{-}\right)$, ammonium $\left(\mathrm{NH}_{4}{ }^{+}\right)$, and iron $(\mathrm{Fe})$, as well as for the determination of cell density and molecular analyses, samples were directly taken through an UWITEC corer equipped with clear acrylic tubes, and then stored in amber jars. For iron quantification, samples were fixed with $\mathrm{HNO}_{3}$, while phosphorus and organic nitrogen determination were fixed with $\mathrm{H}_{2} \mathrm{SO}_{4}$. Samples for the detection of cyanobacteria toxic potential were stored in sterile glass containers and kept at $4{ }^{\circ} \mathrm{C}$ until processing.

\section{Chemical variables quantification}

Chemical variables were analyzed according to the APHA-AWWA-WEF (2012) and the American Society for Testing and Materials (ASTM). Total phosphorus and orthophosphates quantifications were made by a colorimetric method using ascorbic-acid (SM-4500-P-B-E, SM-4500-P-E) and iron by atomic absorption (SM-3111-B). Total organic nitrogen was detected by ionic chromatography according to ASTM: D5176-9; total organic nitrogen, $\mathrm{NO}_{2}^{-}$, $\mathrm{NO}_{3}{ }^{-}$, and $\mathrm{NH}_{4}{ }^{+}$were detected by ionic chromatography according to ASTM D5176- 9, SM $4110 \mathrm{~B}$, $\mathrm{SM} 4500-\mathrm{NO}_{2}{ }^{-} \mathrm{B}$.

\section{Cyanobacteria density}

Cyanobacteria samples from the interface were fixed with $1 \%$ Lugol solution and sedimented according to Utermöhl (1958), then placed in a SedgewickRafter counting chamber. The counting was made in an inverted microscope Leica DM IL with 400X magnification, using the method of random fields with a total of 60 fields per sample. Cyanobacteria were identified following the taxonomic key of Komárek and Anagnostidis (2008) (Chroococcales) and Komárek (2013) (Nostocales). For calculating the cell density of the cyanobacteria, the following equation was used:

cells $/ m L=\frac{n * f 1}{s c h}$

where $n$ is the number of counted cells, $s$ the surface of the microscope field in $\mathrm{mm}^{2}, c$ the number of counted fields, $h$ the hight of the camera in $\mathrm{mm}$, and $f 1$ the conversion factor $\left(10^{3} \mathrm{~mm}^{3} / 1 \mathrm{~mL}\right)$.

\section{Detection of potentially toxic cyanobacteria}

Fifty milliliters of water-sediment interface samples were vacuum filtered through a $0.45 \mu \mathrm{m}$ nitrocellulose filter. The filters were placed in $2 \mathrm{~mL}$ cryogenic vials and stored in a nitrogen tank at $-180^{\circ} \mathrm{C}$ until processing. The extraction of genomic DNA of cyanobacteria was performed according to the method described in the PowerWater Mobio kit (DNA Isolation).

For the amplification of the promoter sequence of microcystin in the gene mcyD (Chroococcales), primers F: 5'-TACGGGAGTAACTTTCGGCTCA-3' and R: 5'-ACAAGCATCTAACATAGCGGGA-3' were used according to Fortin et al. (2010) and for the detection of the mcyE gene (Nostocales), primer sequences F: 5'-CTAGAGTAGTCACTCACGTC-3' and R: 5'-GGTTCTTGATAGTTA

GATTGAGC-3' were used as previously described by Sipari et al. (2010). 
The PCR was carried to a final volume of 30 $\mu \mathrm{L}$, which contained $15 \mu \mathrm{L}$ of a $2 \mathrm{X}$ Master Mix (Thermo Fisher), $3 \mu \mathrm{L}$ of each primer $\mathrm{F}$ and $\mathrm{R}$ at a concentration of $5 \mathrm{mM}, 6 \mu \mathrm{L}$ of PCR water DNAs and RNAs free and $3 \mu \mathrm{L}$ of genomic DNA. The conventional PCR conditions were as follows: an initial denaturation step of $95^{\circ} \mathrm{C}$ for 3 min followed by 40 cycles of $95^{\circ} \mathrm{C}$ for $30 \mathrm{~s}, 56^{\circ} \mathrm{C}$ for $30 \mathrm{~s}$ for the mcyD gene and $53{ }^{\circ} \mathrm{C}$ for the $30 \mathrm{~s} \mathrm{mcyE}$ gene, and $72{ }^{\circ} \mathrm{C}$ for $60 \mathrm{~s}$, followed by a final extension step at $72{ }^{\circ} \mathrm{C}$ for $10 \mathrm{~min}$ and then held at $4{ }^{\circ} \mathrm{C}$. The amplification was carried out in a MultiGene thermal cycler (Optimax Labnet International). The PCR products were separated in a horizontal electrophoresis camera (Labnet) on $3 \%$ agarose gels, to 55 volts for $70 \mathrm{~min}$, using a generuler DNA ladder size of 25-700 pb (ThermoFisher) and observed by a UV transilluminator Spectroline TD-2110E after staining with GelRed nucleic acid gel stain (Biotium) solution for $20 \mathrm{~min}$.

\section{Statistical analysis}

Descriptive analysis and non-parametric tests were applied since assumptions of normality and homoscedasticity were not met. Data analysis was performed using the R software Version 1.2.5033 (Racine 2012, R Core Team, 2013) using the package version 1.13.4 (Galili 2015) and vegan version 2.5- 6 (Oksanen et al. 2015). The hierarchical clustering was performed based on the Euclidean distance as a measure of similarity, while the canonical correspondence analysis (CCA) was performed with the correlations among the physical and chemical factors, nutrients, and the concentration of the four spectral groups of chlorophyll a (green algae, cyanobacteria, diatoms, and cryptophyta). In addition, a Spearman ordinal correlation was carried out in order to determine the association between the physical and chemical variables and the density of Nostocales and Chroococcales cyanobacteria. For the statistical analysis, the software Statgraphics Centurion XVI was used.

\section{RESULTS}

Physical and chemical parameters of the reservoir

Table I shows the depth during the four sampling campaigns, where sampling point 1 had a greater depth (Chico river entry) than sampling points 2 (Las Ánimas entry) and 3 (Grande river entry). $\mathrm{pH}$ varied between 7.0 and 9.5 and was significantly different between sampling sites $(\mathrm{P}=0.025)$. Temperature varied between 15.8 and $18.0{ }^{\circ} \mathrm{C}$ but insignificantly between sampling sites. Conductivity varied between 39.9 and $78.7 \mu \mathrm{S} / \mathrm{cm}$ and was significantly different between sampling sites $(\mathrm{P}=0.048)$. We detected all nitrogen forms $\left(\mathrm{NO}_{2}-, \mathrm{NO}_{3}-\right.$ and $\left.\mathrm{NO}\right)$ but in concentrations lower than $1.36 \mathrm{mg} / \mathrm{L}$, except for ammoniacal nitrogen, which was $2.33 \mathrm{mg} / \mathrm{L}$ at the Chico river entry during March (T1). It was not possible to obtain nitrogen data during time 1 , due to a failure in the ion chromatography equipment, so statistical analyses were made with the average value of the other sampling times for each factor. TP did not exceed $1.0 \mathrm{mg} / \mathrm{L}$ in any of the three sampling sites and the highest average $(0.41 \mathrm{mg} / \mathrm{L})$ was found at the Chico river entry. While the concentration of orthophosphates $\left(\mathrm{PO}_{4}{ }^{3-}\right)$ did not exceed $0.2 \mathrm{mg} / \mathrm{L}$, Fe varied between 5.63 and $0.81 \mathrm{mg} / \mathrm{L}$ (Table II).

\section{Chlorophyll $a$ measurement}

The results of the chlorophyll $a$ measurements of the different spectral groups from the water-sediment interface showed the presence of cyanobacteria at the three sampling sites during all the sampling times (Fig. 2). When Chlorophyta were dominant the other spectral groups (Cyanobacteria, Bacillariophyta/ Dinophyta and Cryptophyta) remained in low proportions. However, when Cyanobacteria dominated only Crytophyta were present (Fig. 2).

The highest percentages of Cyanobacteria chlorophyll $a$ were found at sampling points 1 (Chico river) and 3 (Grande river) during the April (T3) sampling, with 69.4 and $98.5 \%$, respectively. Hierarchical cluster analysis of the sampling sites during the four

TABLE I. CHARACTERISTICS OF THE RIOGRANDE II RESERVOIR DURING THE SAMPLING.

\begin{tabular}{|c|c|c|c|c|c|c|c|c|c|c|c|c|}
\hline \multirow{2}{*}{$\frac{\text { Date }}{\text { Sampling time }}$} & \multicolumn{3}{|c|}{$\mathrm{T} 1$} & \multicolumn{3}{|c|}{$\mathrm{T} 2$} & \multicolumn{3}{|c|}{$\mathrm{T} 3$} & \multicolumn{3}{|c|}{$\mathrm{T} 4$} \\
\hline & 1 & 2 & 3 & 1 & 2 & 3 & 1 & 2 & 3 & 1 & 2 & 3 \\
\hline Sampling depth (m) & 30 & 6.5 & 7.8 & 23 & 8 & 21 & 26 & 20 & 16 & 20 & 16 & 9 \\
\hline Level of the reservoir (\%) & & 92.89 & & & 49.93 & & & 57.35 & & & 47.97 & \\
\hline
\end{tabular}


TABLE II. SPEARMAN'S RANK CORRELATION COEFFICIENT BETWEEN PHYSICAL AND CHEMICAL VARIABLES, AND THE DENSITY OF CYANOBACTERIA IN SAMPLING SITES 1 (CHICO RIVER), 2 (LAS ÁNIMAS), 3 (GRANDE RIVER).

\begin{tabular}{|c|c|c|c|c|c|c|c|c|c|c|c|c|c|c|}
\hline \multirow{2}{*}{$\frac{\text { Sampling time }}{\text { Sampling sites }}$} & \multicolumn{3}{|c|}{ December (T1) } & \multicolumn{3}{|c|}{ March (T2) } & \multicolumn{3}{|c|}{ April (T3) } & \multicolumn{3}{|c|}{ May (T4) } & Chroococcales & Nostocales \\
\hline & 1 & 2 & 3 & 1 & 2 & 3 & 1 & 2 & 3 & 1 & 2 & 3 & \multicolumn{2}{|c|}{ P-value } \\
\hline TP (mg/L) & 0.88 & 0.18 & 0.18 & 0.43 & 0.06 & 0.10 & 0.21 & 0.49 & 0.16 & 0.14 & 0.23 & 0.08 & 0.92 & 0.76 \\
\hline $\mathrm{PO}_{4}{ }^{3-}(\mathrm{mg} / \mathrm{L})$ & 0.11 & 0.01 & 0.04 & 0.07 & 0.02 & 0.02 & 0.05 & 0.10 & 0.02 & 0.09 & 0.19 & 0.06 & 0.25 & 0.69 \\
\hline $\mathrm{Fe}(\mathrm{mg} / \mathrm{L})$ & 5.63 & 2.91 & 2.16 & 5.02 & 0.81 & 1.71 & 3.00 & 4.53 & 2.18 & 1.78 & 3.61 & 1.04 & 0.92 & 0.90 \\
\hline $\mathrm{NO}_{2}^{-}(\mathrm{mg} / \mathrm{L})$ & n.d. & n.d. & n.d. & 0.02 & 0.03 & 0.03 & 0.32 & 0.01 & 0.02 & 0.02 & 0.01 & 0.02 & 0.39 & 0.31 \\
\hline $\mathrm{NO}_{3}^{-}(\mathrm{mg} / \mathrm{L})$ & n.d. & n.d. & n.d. & 0.05 & 0.27 & 0.96 & 0.80 & 0.12 & 1.36 & 0.21 & 0.14 & 0.21 & 0.37 & 0.26 \\
\hline $\mathrm{NH}_{4}^{+}(\mathrm{mg} / \mathrm{L})$ & n.d. & n.d. & n.d. & 2.33 & 0.36 & 0.26 & 0.66 & 1.10 & 0.40 & 0.04 & 0.01 & 0.04 & 0.60 & 0.32 \\
\hline Organic N (mg/L) & n.d. & n.d. & n.d. & 0.32 & 0.28 & 0.39 & 0.31 & 1.17 & 0.33 & 0.34 & 0.25 & 0.26 & 0.45 & 0.40 \\
\hline $\mathrm{Ph}$ (Ph units) & 7.93 & 7.37 & 9.56 & 7.02 & 7.23 & 8.03 & 7.50 & 7.30 & 8.41 & 7.54 & 7.18 & 7.65 & 0.70 & 0.37 \\
\hline $\mathrm{T}\left({ }^{\circ} \mathrm{C}\right)$ & 15.8 & 17.1 & 16.8 & 16.2 & 18.0 & 16.4 & 16.1 & 16.2 & 16.4 & 17.0 & 16.4 & 17.6 & 0.96 & 0.46 \\
\hline Conductivity & 39.9 & 59.7 & 56.1 & 60.7 & 78.7 & 45.7 & 75.8 & 64.7 & 52.8 & 77.1 & 59.7 & 56.7 & 0.50 & 0.88 \\
\hline
\end{tabular}

n.d.: not determined.

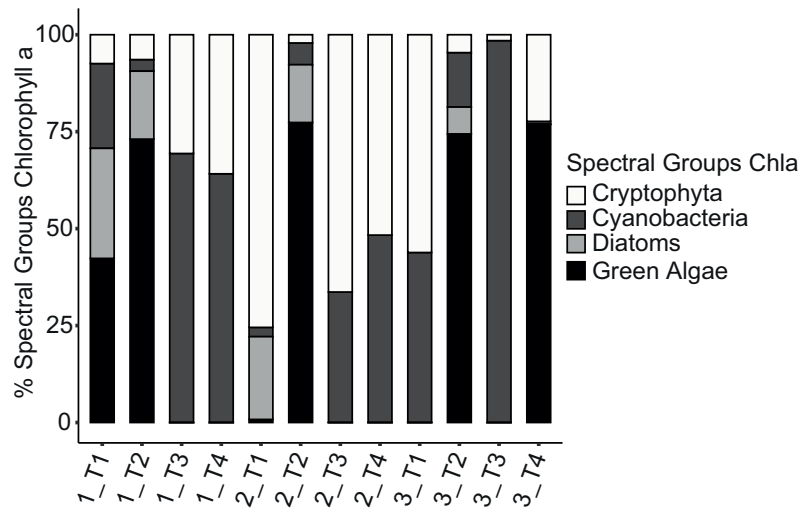

Fig. 2. Chlorophyll $a(\mathrm{Chl} a)$ concentration of the different spectral groups in the water-sediment interface at sampling points 1 (Chico river entry), 2 (Las Ánimas entry), and 3 (Grande river entry), during four sampling times (T1, T2, T3, T4).

sampling times (Fig. $3 \mathrm{~A}$ ) showed a weak grouping between sites related to different chlorophyll $a$ of the spectral groups; therefore, all the sampling sites were similar across the drinking water reservoir. The canonical correspondence analysis (CCA) showed that the concentration of cyanobacteria chlorophyll a was related to $\mathrm{pH}, \mathrm{TP}, \mathrm{Fe}$ and $\mathrm{PO}_{4}{ }^{3-}$. (Fig. 3 B).

Temperature, $\mathrm{PO}_{4}{ }^{3-}$, TP, $\mathrm{Fe}$ and $\mathrm{NH}_{4}{ }^{+}$were the determining environmental variables in the model. Bacillariophyta/Dinophyta chlorophyll $a$ was affected by temperature, conductivity, $\mathrm{NO}_{2}{ }^{-}$and $\mathrm{NO}_{3}{ }^{-}$, while Cryptophyta chlorophyll $a$ was affected by $\mathrm{NH}_{4}{ }^{+}$, conductivity, $\mathrm{NO}_{2}{ }^{-}$and $\mathrm{NO}_{3}{ }^{-}$. The model explained the $92.2 \%$ variance of the data and the CCA1 explained the $74.4 \%$ variance. Regarding cyanotoxin assessment, we focused on Nostocales and Chroococcales because of their potential for producing microcystins.

The variance analysis results did not show significant spatial differences according to the concentrations of total chlorophyll $a$ and chlorophyll $a$ of the blue spectral group in the water-sediment interface. In general, the concentration of total chlorophyll $a$ in the water-sediment interface was lower than $12.4 \mu \mathrm{g} / \mathrm{L}$ and the highest concentrations were presented in the sampling site 3 (Grande river).

\section{Microscopic analyses}

Microcystis aeruginosa, $M$. protocystis and $R a-$ diocystis sp. were reported as a "Microcystis complex" due to: (a) they have similar morphometric characteristics that could not be differentiated when single cells were found in the microscope field, (b) samples contained a great amount of organic matter and the outline of numerous colonies was degraded which is an essential characteristic for the correct identification of cyanobacteria, and (c) these cyanobacteria share similar ecological characteristics (Xiao et al. 2018). While the "Microcystis complex" represented $86 \%$ of the total density of cyanobacteria found in the water-sediment interface, Microcystis wesenbergii just reached $9 \%$ and Sphaerocavum sp. $1.62 \%$ (Fig. 4).

Likewise, Nostocales represented just $3.35 \%$ of the total cyanobacteria found. In the water-sediment 

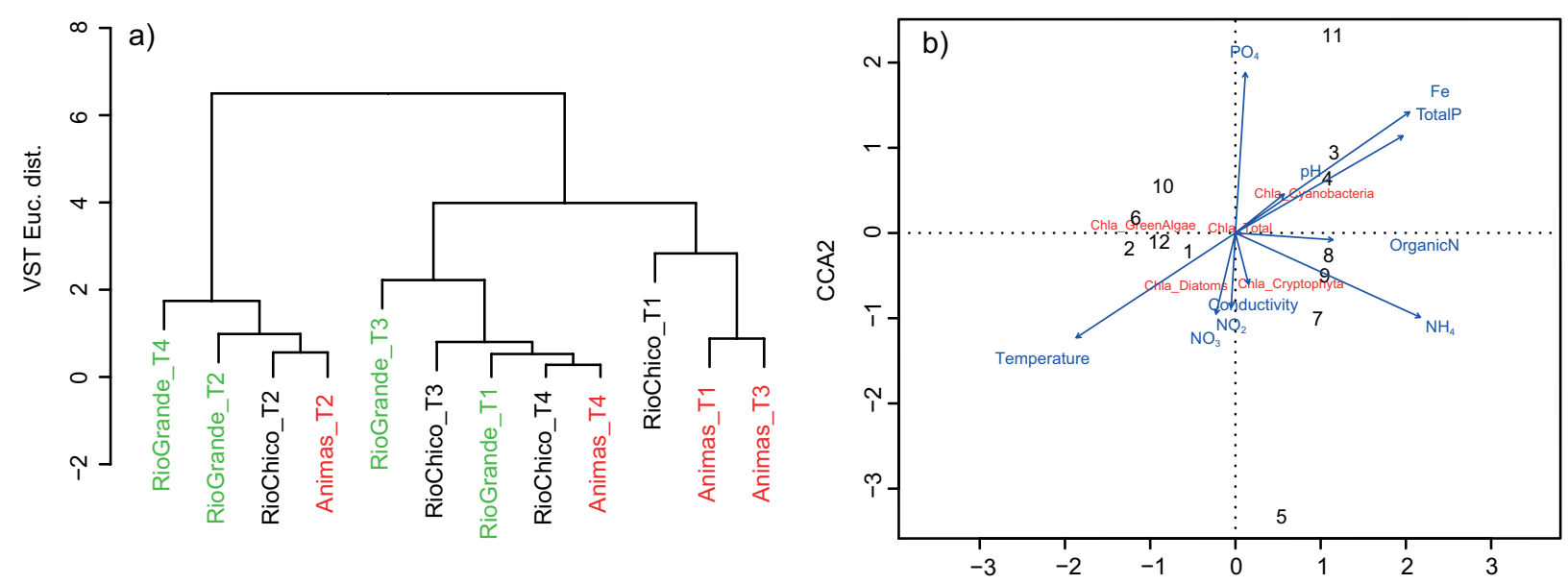

Fig. 3. Spectral groups at the sediment-water interface analyzed by means of (a) hierarchical clustering based on the Euclidean distance as a measure of similarity in the sampling points (Chico river entry, Las Animas entry and Grande river entry) during four sampling times and (b) canonical correspondence analysis (CCA) among the physical and chemical factors, nutrients, and the concentration of the four spectral groups of chlorophyll $a$.

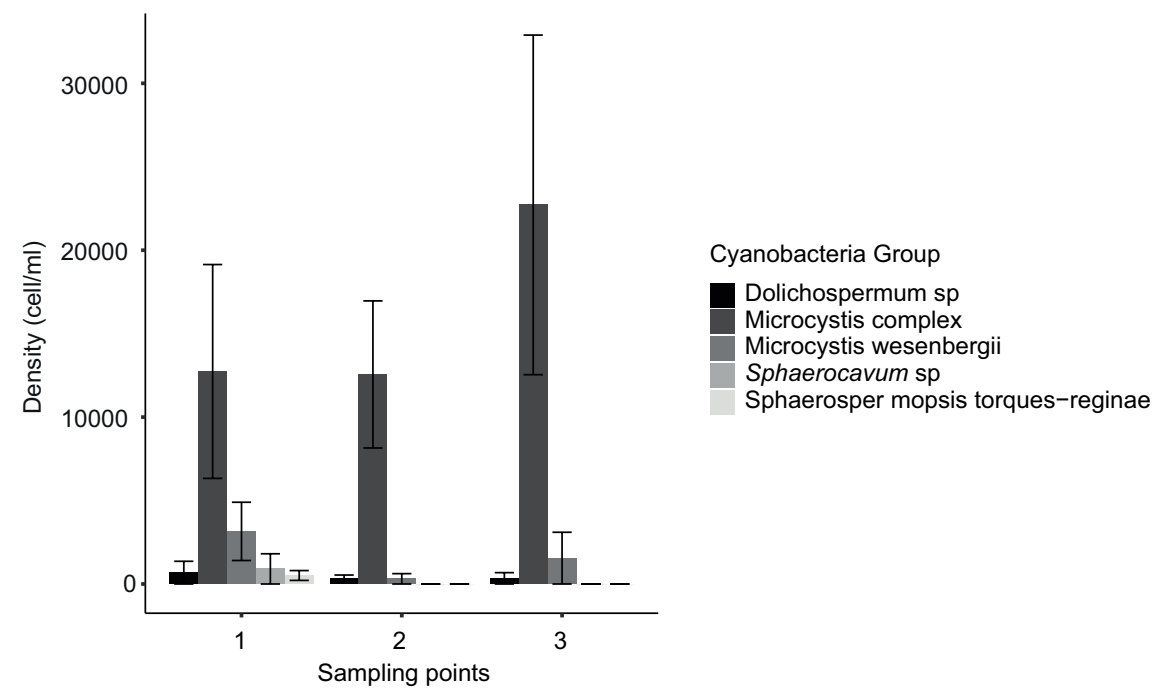

Fig. 4. Density (cell $/ \mathrm{ml})$ of Nostocales and Chroococcales cyanobacteria of the watersediment interface at sampling points 1 (Chico river entry), 2 (Las Ánimas entry), and 3 (Grande river entry).

interface, Microcystis varied between 3540 and 40 000 cells/mL and Dolichospermum between $680 \mathrm{y}$ 2721 cells/mL (Fig. 4). Also, in the water-sediment interface samples, we observed Oscillatoria spp., Phormidium spp. and Pseudanabaena mucicola (Oscillatoriales cynobacteria) attached to the Microcystis mucilage. Among the green algae, Staurastrum was found in all samples and several diatoms were abundant, as expected.
According to the Spearman analysis, densities of Nostocales and Chroococcales across the reservoir stations were not significantly different and they were not correlated with physical and chemical variables with $95 \%$ of reliability.

\section{McyD and mcyE analyses}

The mcyD gene was detected in $58 \%$ of the samples from all sites: Grande river entry in December 
2014; Las Ánimas entry in March 2015; all sampling sites in April 2015, and May 2015 in the Chico and Grande rivers entries. The mcyE gene was detected in $8 \%$ of the samples from the Las Ánimas entry in April 2015 (Table III).

\section{DISCUSSION}

The samplings were carried out in the transition from the wet to the dry season, so it was observed that the level of the reservoir (Table I) was higher in December. During the wet season, the water that enters into the reservoir is colder, so the plume of the Grande river travels to the bottom displacing the warmer waters to the top of the catchment. When the flow of the tributaries is low (dry season), the water is slightly warmer and the Grande river travels intrusively to the catchment below the surface mixing layer, and enters into the arm of the Chico river, so its residence time in the bottom is longer.

Riogrande II is a permanently stratified system with moderate temperature gradients through the water column, with ranges between 16 and $22{ }^{\circ} \mathrm{C}$. According to Palacio et al. (2015), at the beginning of the wet season the Chico river plume moves near the bottom as a result of lower water temperature $\left(16 \pm 1{ }^{\circ} \mathrm{C}\right)$, leading to a slight temperature reduction at the water-sediment interface. However, some values have been recorded ranging from $25{ }^{\circ} \mathrm{C}$ in the photic zone (Palacio-Baena 2015) to $15.8{ }^{\circ} \mathrm{C}$ in the water-sediment interface, as it is observed in Table III. Rosso and Giannuzzi (2017) indicate that water temperature above $20{ }^{\circ} \mathrm{C}$ is one of the most favorable conditions for cyanobacteria development.

Conductivity values in the Chico river entry could be related to its water residence time, which induces the mineralization of substances. The concentration of the different forms of nitrogen in the water-sediment interface could be related to a greater accumulation of organic matter in the sediment $(\mathrm{Pa}-$ lacio et al. 2015).

Some biotic and abiotic factors at the watersediment interface are known to influence the nutrient flows (Gautreau et al. 2020). In the Riogrande II reservoir, the runoff during the rainy season, climatic conditions, erosion and land uses in the basin's tributaries, favor the temporal dynamics of the nutrient loading that enters through the tributaries, which have been related with the proliferation of algae in the reservoir. During an earlier monitoring period between June 2010 and April 2011, the concentration of total phosphorus in the bottom of the reservoir
TABLE III. DETECTION OF THE mcyD AND mcyeE GENES IN CYANOBACTERIA BY PCR.

\begin{tabular}{cccccc}
\hline \multirow{2}{*}{ Time } & \multirow{2}{*}{$\begin{array}{c}\text { Sampling } \\
\text { sites }\end{array}$} & \multicolumn{5}{c}{ PCR result } \\
\cline { 3 - 6 } & & mcyD & $\%$ & mcyE & $\%$ \\
\hline & 1 & - & & - & \\
T1 & 2 & - & 8 & - & 0 \\
& 3 & + & & - & \\
\hline & 1 & - & & - & \\
T2 & 2 & + & 8 & - & 0 \\
& 3 & - & & - & \\
\hline & 1 & + & & - & \\
T3 & 2 & + & 25 & + & 8 \\
& 3 & + & & - & \\
\hline & 1 & + & & - & \\
T4 & 2 & - & 17 & - & 0 \\
& 3 & + & & - & \\
\hline
\end{tabular}

varied between 0.02 and $0.85 \mathrm{mg} / \mathrm{L}$ (Palacio-Baena 2015), similar to the values found in this investigation. Furthermore, the high concentration of total phosphorus of $3349 \mathrm{mg} / \mathrm{kg}$ dry weight in the sediment layer (Gallo-Sánchez 2014) in the Chico river entry can be attributed to agricultural activities in its basin. The lowest concentration of total phosphorus $(0.06 \mathrm{mg} / \mathrm{L})$ was found in the water-sediment interface at the Las Ánimas entry. Nevertheless, the high PT accumulation in the sediment represents a permanent pool that can be activated and released to the water column during the wet season. During the study period, it was determined that the reservoir is hypereutrophic according to the Cunha et al. (2013) index, and the anoxic conditions previously reported by Palacio-Baena (2015) at the sampled sites favor oxide-reduction in the water-sediment interface, therefore it is likely that phosphorus and iron are released from this matrix.

In the water-sediment interface of the three sampling sites, green algae and cryptophytes provided the highest contribution of chlorophyll $a$ (Fig. 2); however, chlorophyll $a$ of the blue spectral group was found in all the sampling points during the four sampling times. Earlier studies show that the presence of eukaryotic phytoplankton in the reservoir is mediated by the biomass of cyanobacteria in temporal dimension, in addition to wet and dry seasons variations (López-Muñoz 2015). Cyanobacteria has an advantage because they can dominate or even displace other groups of phytoplankton due to their special features as accessory pigments and 
their ecological plasticity that allows them to use the low availability of light. In addition, because of their ability to fix N2 within heterocytes (heterocytous) as it is the case with Nostocales cyanobacteria (Cunha et al. 2013, Aguilera et al. 2017). In the current study, Nostocales and Chroococcales in the water-sediment interface were morphologically similar to those reported in the photic zone (Palacio et al. 2015) of the reservoir. In contrast, Head et al. (1999) and Latour et al. (2007) did not find morphological differences between the benthic and pelagic colonies related to the sedimentation of the planktonic species.

Cyanobacteria of the water-sediment interface could be an important recolonization input of potential toxic cyanobaceria to the water column in the reservoir. However, the role of these cyanobacteria for the reinvasion of the water column may depend on various environmental factors that affect their germination as well (Paerl 1988). For example, temperature could be an important factor. Some authors have mentioned that optimal growth temperatures of blooming cyanobacteria are higher than $15^{\circ} \mathrm{C}$ (Jakuwbowsca and Szeląg-Wasielewska 2015, Miller et al. 2017). Rosso and Giannuzzi (2017) indicate that $M$. aeruginosa can also develop blooms with a temperature below $20^{\circ} \mathrm{C}$. As reported in Table III, during the time of this study temperature varied from 15 to $17.6^{\circ} \mathrm{C}$, indicating optimal temperatures for the presence of Nostocales and Chroococcales at the water-sediment interface.

The tributary flow is another factor that can promote cyanobacteria blooms, since increased water flow during rainy periods can lead to sediment resuspension, combined with the transport of accumulated nutrients in the sediment into the water column (Palacio-Betancur 2014). These nutrients could increase the existing phytoplankton biomass or modify the community structure to greater competitiveness among some bloom forming species like cyanobcteria (Wells et al. 2015).

Iron is an important element in cyanotoxins synthesis. Low concentrations of this metal have been related to the increased production of microcystins and cell growth of cyanobacteria (Neilan et al. 2013, Lukac and Aegerter 1993). Martín et al. (2002) highlight the expression of microcystin regulation through the enzyme FUR, which is activated by iron. In consequence, low iron concentrations favor cyanotoxin expression due to the inhibition of the regulatory enzyme (FUR) of the mcy operon expression (Sevilla et al. 2008). Bolaños-Benítez (2012) found total values of iron in the sediment between 1.8 and $27.5 \mathrm{mg} / \mathrm{L}$, determining a higher concentration in the Chico river entry. However, there is not available data regarding the sediment-water interface. According to Gallo-Sánchez (2014), conditions in the superficial sediments, especially at the entrance of the Chico river, favor the retention and release of iron. It has also been shown that M. aeruginosa colonies are able to support limitations of iron facilitating metabolic processes (Xiao et al. 2018). In this research we found that iron influenced the presence of cyanobacteria in the Riogrande II reservoir (Fig. 3b). Accordingly, sample point 1 had the highest iron concentration and Palacio-Betancur (2014) indicated that Chico river tributary is a "hot spot" for cyanobacteria presence due to the nutrients from the basin and the characteristics of the sediment.

The presence of Nostocales and Chroococcales cyanobacteria with toxic potential in the watersediment interface of the Riogrande II reservoir is probably related to the species' life cycle characteristics or the drag effect of the tributaries entering the reservoir, especially when currents move near the bottom and resuspend the sediments.

In this regard, akinetes allow Nostocales to survive in the sediments for long periods of time, and once the environmental conditions are favorable (such as a proper temperature, little vertical mixing and turbidity), they can germinate, form gas vesicles and migrate to the water column (Everson et al. 2011, Mowe et al. 2014). Environmental conditions play an important role in the life cycle of some Nostocal species, because lower temperatures $\left(10-15^{\circ} \mathrm{C}\right)$, darkness, and low oxygen levels (1-2 mg/L) favor the viability of the cells located near the surface of the sediment (Karlsson-Elfgren and Brunberg 2004, Everson et al. 2011). Also, the regulation of their buoyancy develops gradually and independently of cell turgor and light conditions (Walsby 1991). While some Nostocales such as Anabaena can migrate up to a 50-m depth, nitrogen-fixing species such as Microcystis are able to move up to $140 \mathrm{~m}$ through the water column (Reynolds 1972).

With respect to the Chroococcales order, a higher density of Chroococcales cyanobacteria found in the three sampling points (figure 4). According to Boström et al. (1989), some Chroococcales such as Microcystis aeruginosa can survive in vegetative form for long periods in surface sediments. This behavior has been associated with the presence of mucilage in their colonies (Bauza and Giannuzzi 2011). Microcystis is one of the best-studied genera: in temperate zones it has a benthic phase during its 
life cycle and has the ability to form blooms and to produce microcystins in freshwater ecosystems, affecting the water quality management (Cirés et al. 2013); it is also one of the most reported in tropical environments, America not being the exception (Mowe et al. 2014, Aguilera et al. 2018). The study in the Riogrande II reservoir confirmed that cyanobacteria can survive in a 23-m depth.

Latour et al. (2004, 2007) and Misson and Latour (2012) reported that in deep lakes Microcystis are also capable of surviving without the annual return to a planktonic stage and retain the ability to grow later. It has also been found that cells that migrate and reinvade the water column can belong to new colonies arising within the mucilage from the parent colony, after a short phase of cell division. The maintenance of cellular integrity requires energy, which is why the colony decreases its enzymatic activity in the sediment (Latour et al. 2007). The cellular environment, mediated by the amount of organic matter and low oxygen concentrations $(<2 \mathrm{mg} / \mathrm{L})$, could promote alternatives of oxygenic photosynthesis as a basis for the growth of the cells. Also, it has been shown that cells of Microcystis from the water-sediment interface were viable during significant periods of time when glycogen stores were depleted. As the colony ages, the peripheral cells dye; however, cells remain in good physiological conditions in the center with a structure comparable to the planktonic colonies, which allows them to grow and preserve intracellular toxins (Reynolds et al. 1981).

Due to the bimodal Colombian climate, during long periods of dry weather the reservoir level drops, thereby the cyanobacteria remain as resistant forms in the sediment. According to Paerl et al. (2011) most species that produce blooms can survive environmental stress for long periods in deep zones. It has also been shown that the distribution of Microcystis in sediments is influenced by factors such as the nature of the substrate, the depth of the hydraulic system, the dynamics and the morphometry of the system (Latour and Giraudet 2004, Latour et al. 2004, 2007), and the transport and sedimentation of cells and physiological characteristics that allow them to adapt to this kind of environments. In addition, when stratification is longer and the depth is greater in the systems, large mucilaginous colonies as M. aeruginosa can be found (Aguilera et al. 2017) corresponding with the results of this research (Palacio-Baena 2015).

According to the above, the plumes of the tributaries entering the Riogrande II reservoir, could be generating the processes of sediments resuspension, which could have an impact on the recruitment of cyanobacteria to the water-sediment interface. According to Palacio et al. (2015) during the rivers low flow and reduced levels of the reservoir, colonial forms (particularly Microcystis) dominated in the photic zone. These results are consistent with those found in this study, where the highest densities of cyanobacteria were observed when the reservoir level was lower than $60 \%$ (Fig. 4).

The recruitment of Microcystis to the water column from the benthic zone is also given by processes of resuspension (Verspagen et al. 2004). According to Ståhl-Delbanco et al. (2003), Rinta-Kanto et al. (2009) and Misson and Latour (2012), the recruitment of Microcystis from the sediment is also regulated by active and passive processes of buoyancy that depend on the sediment mixture. The resuspension of colonies resulting from the dragging of deep water masses as a result of the filling of the reservoir from the bottom could be important in the recruitment of Microcystis. In this way, benthic colonies could be an inoculum for the development of possible blooms of this species, as pointed out by Rinta-Kanto et al. (2009). Between 2006 and 2007, a cyanobacterial bloom formed by Microcystis aeruginosa, $M$. wesenbergii, M. protocystis, Radiocystis sp., and Anabaena sp. was evidenced mainly in site 1 of the Riogrande II reservoir, with orthophosphate values greater than $0.1 \mathrm{mg} / \mathrm{L}$ (Palacio-Betancur 2014). Nutrients such as phosphorous and nitrogen can influence the formation colonies of Microcystis spp. (Xiao et al. 2018). According to this, the recruitment or presence of cyanobacteria would not only be mediated by resuspension processes but also by the time of water residence on the site. Furthermore, resuspension processes could not only release cyanobacteria from the sediment, but also nutrients such phosphorus that may become available to cyanobacteria in the water column.

Although the percentage of cells containing genes that produce toxins may vary in time and space (Beversdorf et al. 2015), the mcyD gene was detected in Chroococcales present in all sampling points (Table III), which is associated with the highest density of "Microcystis complex" reported. Although the mcyE gene was only detected at one sampling point, it was possible to find Nostocales cyanobacteria, especially during sampling time T3 (Fig 4). In the same study period, Arboleda-Baena (2016) reported that Dolichospermum fluctuated between 284 and 7000 cells/mL and Microcystis between 827 and 4000 cells $/ \mathrm{mL}$ in the water column, which indicates that the highest densities of cyanobacteria were found at the water-sediment interface. The detection of mcy genes in the water-sediment interface samples demonstrate 
the presence of cyanobacteria with toxic potential in a drinking water reservoir (Table III). However, the detection of these genes would not necessarily indicate the production of microcystins; therefore, it would be relevant to measure cyanotoxins directly in the samples obtained from the water-sediment interface or alternatively to measure the RNA expression of these genes in the cyanobacteria.

Consequently, this study is the first report that establishes a benthic phase in the life cycle of $M i-$ crocystis in tropical environments, which could be influenced by factors not yet identified in the reservoir. So, it is important to consider more sampling points and new sampling methods at the reservoir water-sediment interface to better understand the life cycles, interactions and processes that influence cyanobacteria in stratified systems, according to Wells et al. (2015). Finally, this research is also the first evidence of cyanobacteria with toxic potential in the water-sediment interface of a stratified and relatively deep tropical system, pointing out potential risks of cyanotoxins production and possible reinvasion to the water column of a system used for drinking water.

\section{CONCLUSIONS}

The measurements of the investigated spectral groups in the water-sediment interface were equally distributed at the three sampling sites and times. The greatest contribution to total chlorophyll $a$ in the samples was due to chlorophytes and cryptophytes.

Within the total number of cyanobacteria, Nostocales represented $3.35 \%$ and the "Microcystis complex" corresponded to $86 \%$. Through the amplification of genes involved in the synthesis of microcystins, the mcyD gene was evident in all the sampling points and the mcyE gene was only found at Las Animas entry in April 2015. The presence of cyanobacteria could negatively affect the drinking water quality and constitutes a human health risk. This emphasizes the need for a permanent monitoring of cyanobacteria in the water-sediment interface of drinking water reservoirs including cyanotoxin analysis in situ and the evaluation of genes encoding other toxins, with the purpose of implementing guideline values and risk management frameworks in Mexico.

\section{ACKNOWLEDGMENTS}

This study was possible thanks to the financial support of Colciencias (658-2014) project
111565843084 and Empresas Públicas de Medellín (EPM). The laboratory analysis support was provided by Grupo de Investigación en Gestión y Modelación Ambiental-GAIA.

\section{REFERENCES}

Aguilera A., Aubriot L., Echenique O.R., Salerno G.L., Brena B.M., Pírez M. and Bonilla S. (2017). Synergistic effects of nutrients and light favor Nostocales over non-heterocystous cyanobacteria. Hidrobiologica 794, 241-255. https://doi.org/10.1007/s10750-017-3099-1

Aguilera A. and Echenique R.O. (2017). Cyanobacteria nocivas de ambientes acuáticos continentales: taxonomía y ecología. In: Cianobacterias como determinantes ambientales de la salud (Giannuzzi L., Petcheneshsky L. and Hansen M., Ed.). Ministerio de Salud de la Nación, Buenos Aires, Argentina, 27-48.

Aguilera A., Haakonsson S., Martín M.V., Salerno G.L. and Echenique R.O. (2018). Bloom-forming cyanobacteria and cyanotoxins in Argentina: A growing health and environmental concern. Limnologica 69, 103-114. https://doi.org/10.1016/j.limno.2017.10.006

APHA-AWWA-WEF (2012). Standard methods for the examination of water and wastewater. Guide. American Public Health Association, Washington DC, 1278 pp.

Arboleda-Baena C.M. (2016). Determinación del potencial tóxico de cianobacterias Nostocales y Chroococcales en la columna de agua del embalse Riogrande II (Antioquia) a través de la detección del gen mcy. M.Sc. Thesis. Corporación Académica Ambiental, Universidad de Antioquia, Medellín, Colombia, 91 pp.

Bauzá L. and Giannuzzi L. (2011). Métodos de control del desarrollo de floraciones cianobacterianas en ambientes acuáticos. In: Cianobacterias como determinantes ambientales de la salud (Giannuzzi L., Ed.). Ministerio de Salud de la Nación, Buenos Aires, Argentina, 117-138.

Beutler M., Wiltshire K.H., Lüring C., Moldaenke C., Meyerhöfer M., Hansen U.P. and Dau H. (2002). A fluorometric method for the differentiation of algal populations in vivo and in situ. Photosynth. Res. 72, 39-53. https://doi.org/10.1023/A:1016026607048

Beversdorf L.J., Chaston, S.D., Miller T.R. and McMahon K.D. (2015). Microcystin mcyA and mcyE gene abundances are not appropriate indicators of microcystin concentrations in lakes. Plos One 10 (5), 1-18. https:// doi.org/10.1371/journal.pone. 0125353

Bolaños-Benítez S.V. (2012). Potencial de liberación de $\mathrm{Fe}, \mathrm{Mn}, \mathrm{Cr}$ y $\mathrm{Pb}$ de los sedimentos de los embalses La Fe y Riogrande II, Antioquia, bajo condiciones de laboratorio. M.Sc. Thesis. Facultad de Ingeniería, Universidad de Antioquia, Medellín, Colombia, 207 pp. 
Bonilla S., Haakonsson S., Somma A., Gravier A., Britos A., Vidal L., de León L., Brena B., Pírez M., Piccini C., Martínez de la Escalera G., Chalar G., Gonzáles Piana M., Martigani F. and Aubriot L. (2015). Cianobacterias y cianotoxinas en ecosistemas límnicos de Uruguay. Innotec 10, 9-22.

Boopathi T. and Ki J-S. (2014). Impact of environmental factors on the regulation of cyanotoxin production. Toxins 6, 1951-1978. https://doi.org/10.3390/toxins6071951

Boström B., Pettersson A. and Ahlgren, I. (1989). Seasonal dynamics of a cyanobacteria-dominated microbial community in surface sediments of a shallow, eutrophic lake. Aquat. Sci. 51 (2), 153-178. https://doi. org/10.1007/BF00879300

Brunberg K. and Blomqvist P. (2002). Benthic overwintering of Microcystis colonies under different environmental conditions. J. Plankton. Res. 24 (11), 1247-1252. https://doi.org/10.1093/plankt/24.11.1247

Bula-Meyer G. (1985). Florecimientos nocivos de algas verde-azules en dos lagunas del departamento del Magdalena. Revista Ingeniería Pesquera 5, 89-99.

Cao X., Wang Y., He J., Luo X. and Zheng Z. (2016). Phosphorus mobility among sediments, water and cyanobacteria enhanced by cyanobacteria blooms in eutrophic Lake Dianchi. Environ. Pollut. 219, 580-587. https://doi.org/10.1016/j.envpol.2016.06.017

Chaffin J.D., Davis T.W., Smith D.J., Baer M.M. and Dick G.J. (2018). Interactions between nitrogen form, loading rate, and light intensity on Microcystis and Planktothrix growth and microcystin production. Harmful Algae 73, 84-97. https://doi.org/10.1016/j.hal.2018.02.001

Chorus I. (2012). Current approaches to cyanotoxin risk assessment, risk management and regulations in different countries. Federal Environment Agency, Berlin, Germany, $117 \mathrm{pp}$.

Cirés S, Wörmer L, Carrasco D. and Quesada A. 2013. Sedimentation patterns of toxin-producing Microcystis morphospecies in freshwater reservoirs. Toxins 5, 939957. https://doi.org/10.3390/toxins5050939

Correa I.C. (2008). Toxicidad de florecimientos de cianobacterias en el embalse Riogrande II. M.Sc. Thesis. Facultad de Ingeniería, Universidad de Antioquia, Medellín, Colombia, 120 pp.

Cunha D.G.F., Calijuri M.D.C. and Lamparelli M.C. (2013). Trophic state index for tropical/subtropical reservoirs (TSI Isrr ). Ecol. Eng. 60, 126-134. https://doi. org/10.1016/j.ecoleng.2013.07.058

Elliot J.A. (2012). Is the future blue-green? A review of the current model predictions of how climate change could affect pelagic freshwater cyanobacteria. Water. Res. 46, 1364-1371. https://doi.org/10.1016/j.watres.2011.12.018
Everson S., FabBro L., Kinnear S. and Wright P. (2011). Extreme differences in akinete, heterocyte and cylindrospermopsin concentrations with depth in a successive bloom involving Aphanizomenon ovalisporum (Forti) and Cylindrospermopsis raciborskii (Woloszynska) Seenaya and Subba Raju. Harmful Algae 10, 265-276. https://doi.org/10.1016/j.hal.2010.10.006

Fortin N., Aranda-Rodríguez R., Jing H., Pick F., Bird D. and Greer C.W. (2010). Detection of Microcystinproducing cyanobacteria in Missisquoi Bay, Quebec, Canada, using quantitative PCR. Appl. Environ. Microbiol. 76 (15), 5105-5112. https://doi.org/10.1128/ AEM.00183-10

Galili T. (2015). Dendextend: An R package for visualizing, adjusting, and comparing trees of hierarchical clustering. Bioinformatics 31 (22), 3718-3720. https:// doi.org/10.1093/bioinformatics/btv428

Gallo-Sánchez L.J. (2014). Reconstrucción del estado trófico de tres embalses colombianos a través de la relación entre la geoquímica por (NIRS) y las diatomeas presentes en el sedimento superficial y en núcleos de sedimento. PhD. Thesis. Instituto de Biología, Universidad de Antioquia, Medellín, Colombia, 298 pp.

Gangi D., Plastani M.S., Laprida C., Lami A., Dubois N., Bordet Gorgoza C., Frau D. and de Tezanos Pinto P. (2020). Recent cyanobacteria abundance in a large sub-tropical reservoir inferred from analysis of sediment cores. J. Paleolimnol. 63 (3), 195-209. https:// doi.org/10.1007/s10933-020-00110-8

Gautreau E., Volatier L., Nogaro G., Gouze E. and Mermillod-Blondin F. (2020). The influence of bioturbation and water column oxygenation on nutrient recycling in reservoir sediments. Hydrobiologia 847, 1027-1040. https://doi.org/10.1007/s10750-019-04166-0

Gregor J. and Maršálek B. (2004). Freshwater phytoplankton quantification by chlorophyll $a$ : a comparative study of in vitro, in vivo and in situ methods. Water. Res. 38 (3), 517-522. https://doi.org/10.1016/j.watres.2003.10.033

Head R.M., Jones R.I. and Bailey-Watts A.E. (1999). An assessment of the influence of recruitment from the sediment on the development of planktonic populations of cyanobacteria in a temperate mesotrophic lake. Freshwater. Biol. 41 (4), 759-769. https://doi. org/10.1046/j.1365-2427.1999.00421.x

Herrera N.A., Fernando L. and Ferrao A.S. (2015). Effects of phytoplankton extracts containing the toxin microcystin-LR on the survival and reproduction of cladocerans. Toxicon 95, 38-45. https://doi.org/10.1016/j. toxicon.2014.12.016

Jakubowsca N. and Szeląg-Wasielewska E. (2015). Toxic picoplanktonic cyanobacteria - review. Mar. Drugs. 13, 1497-1518. https://doi.org/10.3390/md13031497 
Karlsson-Elfgren I. and Brunberg A. (2004). The importance of shallow sediments in the recruitmen of Anabaena and Aphanizomenon (cyanophyceae). J. Phycol. 40 (5), 831-836. https://doi.org/10.1111/j.15298817.2004.04070.x

Komárek J. and Anagnostidis K. 2008. Cyanoprokaryota 1. Teil/part 1: Chroococcales. In: Süßwasserflora von Mitteleuropa (Freshwater flora of Central Europe) (Ettl H., Gerloff J., Heynig H. and Mollenhauer D., Eds.). 19/1. Spektrum, Berlin, 548 pp.

Komárek J. (2013). Cyanoprokaryota 3. Teil/part 3: Heterocytous genera. In: Süßwasserflora von Mitteleuropa (Freshwater flora of Central Europe) (Büdel B., Gärtner G., Krienitz L. and Schagerl M., Eds.). 19/3. Spektrum, Berlin, 1130 pp.

Ladakis M., Dassenakis M. and Pantazidou A. (2006). Nitrogen and phosphorus in coastal sediments covered by cyanobacteria mats. J. Soils. Sediment. 6(1), 46-54. https://doi.org/10.1065/jss2005.10.150

Latour D. and Giraudet H. (2004). Factors influencing the spatio-temporal distribution of benthic Microcystis aeruginosa colonies (Cyanobacteria) in the hypertrophic Grangent reservoir (Loire, France). CR. Biol. 327 (8), 753-761. https://doi.org/10.1016/j.crvi.2004.07.003

Latour D., Sabido O., Salençon M.J. and Giraudet H. (2004). Dynamics and metabolic activity of the benthic cyanobacterium Microcystis aeruginosa in the Grangent reservoir (France). J. Plankton. Res. 26 (7), 719-726. https://doi.org/10.1093/plankt/fbh075

Latour D., Salençon M.J., Reyss J.L. and Giraudet H. (2007). Sedimentary imprint of Microcystis aeruginosa (cyanobacteria) blooms in Grangent reservoir (Loire, France). J. Phycol. 43 (3), 417-425. https://doi. org/10.1111/j.1529-8817.2007.00343.x

López Muñoz M.T. (2015). Aspectos ecológicos y taxonómicos del fitoplancton eucariótico del embalse Riogrande II (Antioquia, Colombia). PhD. Thesis. Facultad de Ciencias Exactas y Naturales, Universidad de Antioquia, Medellín, Colombia, 182 pp.

Lukac M. and Aegerter R. (1993). Influence of trace metals on growth and toxin production of Microcystis aeruginosa. Toxicon 31 (3), 293-305. https://doi. org/10.1016/0041-0101(93)90147-B

Lürling M., Eshetu F., Faassen E., Kosten S. and Huszar V.L.M. (2013). Comparison of cyanobacterial and green algal growth rates at different temperates. Freshwater. Biol. 58 (2013), 552-559. https://doi. org/10.1111/j.1365-2427.2012.02866.x

Mancera J.E. and Vidal L.A. (1994). Florecimiento de microalgas relacionado con mortandad masiva de peces en el complejo lagunar Ciénaga Grande de Santa Marta, Caribe Colombiano. Boletín de Investigaciones Marinas y Costeras-Invemar 23 (1), 103-117.
Martín B., Hernández J.A., López S., Inda L.A., Bes M.T., Fillat M.F. and Peleato M.L. (2002). Estudios de homología entre regiones del operón mcy de Microcystis aeruginosa PCC 7806 y muestras procedentes de La Estanca de Alcañiz (Teruel). Revista de la Academia de Ciencias Exactas, Físicas, Químicas y Naturales de Zaragoza (57), 231-239.

Mesquita M.C.B., Prestes A.C.C., Gomes A.M.A. and Marinho M.M. (2019). Direct effects of temperature on growth of different tropical phytoplankton species. Microb. Ecol. 79, 1-11. https://doi.org/10.1007/ s00248-019-01384-w

Metcalf J.S. and Codd G.A. (2009). the status and potential of cyanobacteria and their toxins as agents of bioterrorism. In: Handbook on cyanobacteria (Gault P.M.H. and Marler J., Eds.). Nova Science Publishers, New York, 259-275.

Miller T.R., Beversdorf L.J., Weirich C.A. and Bartlett S.L. (2017). Cyanobacterial toxins of the Laurentian great lakes, their toxicological effects, and numerical limits in drinking water. Mar. Drugs. 15 (6), 1-51. https://doi. org $/ 10.3390 / \mathrm{md} 15060160$

Misson B. and Latour D. (2012). Influence of light, sediment mixing, temperature, and duration of the benthic life phase on the benthic recruitment of Microcystis. J. Plankton. Res. 34 (2), 113-119. https://doi.org/10.1093/ plankt/fbr093

Mowe M.A.D., Mitrovic S.M., Lim R.P. Furey A. and Yeo D.C.J. (2014). Tropical cyanobacterial blooms: a review of prevalence, problem taxa, toxins and influencing environmental factors. J. Limnol. 74 (2), 205-224. https://doi.org/10.4081/jlimnol.2014.1005

Neilan B., Pearson L., Muenchhoff J. and Moffitt M. (2013). Environmental conditions that influence toxin biosynthesis in cyanobacteria. Environ. Microbiol. 15 (5), 1239-1253. https://doi.org/10.1111/j.14622920.2012.02729.x

Oksanen J., Blanchet F.G., Friendly M., Kindt R., Legendre P., McGlinn D., Minchin P.R., O'Hara R.B., Simpson G.L., Solymos P., Stevens M.H.H., Szoecs E. and Wagner H. (2015). Community ecology package v. 2.5-6 [online]. https://cran.r-project.org/web/packages/ vegan/vegan.pdf 01/04/2020

Paerl H.W. (1988). Nuisance phytoplankton blooms in coastal, estuarine, and inland waters. Limnol. Oceanogr. 33 (4_part_2), 823-843. https://doi.org/10.4319/ lo.1988.33.4_part_2.0823

Paerl H.W., Hall N.S. and Calandrino E.S. (2011). Controlling harmful cyanobacterial blooms in a world experiencing anthropogenic and climatic-induced change. Sci. Total. Environ. 409 (10), 1739-1745. https://doi. org/10.1016/j.scitotenv.2011.02.001

Palacio H.M., Ramírez J.J., Echenique R.O., Alberto J. and Leite Sant'anna C. (2015). Floristic composition 
of cyanobacteria in a neotropical, eutrophic reservoir. Braz. J. Bot. 38 (1), 1-14. https://doi.org/10.1007/ s40415-015-0185-3

Palacio-Baena J.A. (2015). Estudio de la problemática ambiental de tres embalses de empresas públicas de Medellín para la gestión integral y adecuada del recurso hídrico (informe técnico). Universidad de Antioquia, Medellín, Colombia, 490 pp.

Palacio-Betancur H.M. (2014). Dinámica espacio-temporal de las cianobacterias en el embalse Riogrande II. PhD. Thesis. Instituto de Biología, Universidad de Antioquia, Medellín, Colombia, 185 pp.

Quiblier C., Wood S., Echenique-Subiabre I., Heath M., Velleneuve A. and Jean-François H. (2013). A review of current knowledge on toxic benthic freshwater cyanobacteria -Ecology, toxin production and risk management. Water. Res. 47, 5464-5479. https://doi. org/10.1016/j.watres.2013.06.042

R Core Team (2013). R: a language and environment for statistical computing. R Foundation for Statistical Computing, Vienna, Austria [online]. https://www.Rproject.org/ 01/04/2020

Racine J.S. (2012). Rstudio: a platform-independent IDE for R and Sweave. J. Appl. Econom. 27, 167-172. https://doi.org/10.1002/jae.1278

Reynolds C.S. (1972). Growth, gas vacuolation and buoyancy in a natural population of a planktonic blue-green alga. Freshwater. Biol. 2 (2), 87-106. https://doi.org/ 10.1111/j.1365-2427.1972.tb00364.x

Reynolds C.S., Jaworski G.H.M., Cmiech H.A. and Leedale G.F. (1981). On the annual cycle of the blue-green alga Microcystis Aeruginosa Kütz. Emend. Elenkin. Philos. T. R. Soc. B 293 (1068), 419-477. https://doi. org/10.1098/rstb.1981.0081

Rinta-Kanto J.M., Saxton M.A., DeBruyn J.M., Smith J.L., Marvin C.H., Krieger K.A., Sayler GS., Boyer GL. and Wilhelm S.W. (2009). The diversity and distribution of toxigenic Microcystis spp. in present day and archived pelagic and sediment samples from Lake Erie. Harmful Algae 8 (3), 385-394. https://doi. org/10.1016/j.hal.2008.08.026

Rosso L. and Giannuzzi L. (2017). Factores ambientales y antropogénicos que afectan la formación de floraciones de cianobacterias y cianotoxinas. In: Cianobacterias como determinantes ambientales de la salud (Giannuzzi L., Petcheneshsky L., Hansen M., Eds.). Ministerio de Salud de la Nación, Buenos Aires, Argentina, 79-93.

Sevilla E., Martín-Luna B., Vela L., Bes M.T., Fillat M.F. and Peleato M.L. (2008). Iron availability affects $m c y D$ expression and microcystin-LR synthesis in
Microcystis aeruginosa PCC7806. Environ. Microb. 10 (10), 2476-2483. https://doi.org/10.1111/j.14622920.2008.01663.x

Sipari H., Rantala-Ylinen A., Jokela J., Oksanen I. and Sivonen K. (2010). Development of a chip assay and quantitative PCR for detecting microcystin synthetase e gene expressions. Appl. Environ. Microb. 76 (12), 3797-3805. https://doi.org/10.1128/AEM.00452-10

Ståhl-Delbanco A., Hansson L.A. and Gyllstrom M. (2003). Recruitment of resting stages may induce blooms of Microcystis at low N:P ratios. J. Plankton. Res. 25 (9), 1099-1106. https://doi.org/10.1093/ plankt/25.9.1099

Teixeira M.R. (2009). Assessing the health risk of flotationnanofiltration sequence for cyanobacteria and cyanotoxin removal in drinking water. In: Handbook on cyanobacteria: biochemistry, biotechnology and applications (bacteriology research developments) (Gault P.M.H., Ed.). Nova Science Publishers, New York, 349-389.

Tsujimura S., Tsukada H., Nakahara H., Nakajima T. and Nishino M. (2000). Seasonal variations of Microcystis populations in sediments of Lake Biwa, Japan. Hydrobiologia 434, 183-192. https://doi.org/10.1023/ A:1004077225916M

Utermöhl H. (1958). Zur Vervollkommung der quantitativen Phytoplankton-Methodik. Mitt Int. Ver. Limnol. 9 (2713), 1-39.

Verspagen J.M.H., Snelder E.O.F.M., Visser P.M., Huisman J., Mur L.R. and Ibelings B.W. (2004). Recruitment of benthic Microxystis (Cyanophyceae) to the water column: internal buoyancy changes or resuspension. J. Phycol. 270, 260-270. https://doi. org/10.1111/j.1529-8817.2004.03174.x

Walsby A.E. (1991). The mechanical properties of the Microcystis gas vesicle. Microbiology 137 (10), 24012408. https://doi.org/10.1099/00221287-137-10-2401

Wells M.L., Trainer V.L., Smayda T.J., Karlson B.S.O., Trick C.G., Kudela R.M., Ishikawa A., Bernand S., Wullf A., Anderson D.M. and Cochlan W.P. (2015). Harmful algal blooms and climate change: learning from the past and present to forecast the future. Harmful Algae 49, 68-93. https://doi.org/10.1016/j.hal.2015.07.009

Xiao M., Li M. and Reynolds C.S. (2018). Colony formation in the cyanobacterium Microcystis. Biol. Rev. 93 (3), 1399-1420. https://doi.org/10.1111/brv.12401

Ye W., Tan J., Liu X., Lin S., Pan J., Li D. and Yang H. (2011). Temporal variability of cyanobacterial populations in the water and sediment samples of Lake Taihu as determined by DGGE and real-time PCR. Harmful Algae 10 (5), 472-479. https://doi.org/10.1016/j. hal.2011.03.002 